\title{
Effect of Pregnancy, Lactation Stage, Parity and Age on Yield and Components of Raw Milk in Holstein Friesian Cows in organized Dairy form in Allahabad
}

\author{
AkhandPratap $^{1 *}$, Deepak Kumar Verma ${ }^{2 *}$, P. Kumar ${ }^{3 *}$ and Ajit Singh ${ }^{4 *}$ \\ Department of Live Stock Production \& ManagementSundereson School of Animal Husbandary\& Dairying \\ SHIATS Allahabad,
}

\begin{abstract}
The experiment was carried out on lactating Holstein Friesian cows with the objectives of evaluating the effect of stage of age, pregnancy, lactation, parity and on yield, and components (fat, protein, solid not fat and lactose) and $\mathrm{pH}$ of milk. Milk samples were directly collected from the teat and immediately analysed using milk. The result showed that lactation stage and pregnancy significantly $(P<0.05)$ affected the milk yield whereas milk yield did not show significant variation in different age and parity groups. The highest yield was recorded in mid stage and lowest in late stage of lactation. The yield was higher in non-pregnant than pregnant cows. The fat content of the milk was significantly higher $(P<0.05)$ in early and late than mid stage of lactation. However, fat content was not significantly varying with age, pregnancy and parity. The solid not fat (SNF) and protein contents of the milk were significantly different in pregnancy and age but it was not significantly affected by stage of lactation and parity. The lactose content of the milk was affected significantly $(P<0.05)$ by pregnancy only. But the $\mathrm{pH}$ of the milk was not affected significantly by stages of lactation, pregnancy, age and parity of the cows. This study indicated that different factors affect the milk yield and milk components.
\end{abstract}

Key words: Cows, Holstein Friesian, Lactation Stage, Pregnancy, Parity, Age

\section{Introduction}

Milk is a fluid secreted by the mammary glands of mammals to feed their young. It is a good source nutrients and hence important for growth, repairs and provides energy. The nutritive value varies with its composition. The composition of cows' milk is also of the greatest importance for the dairy industry. Since, its processability is highly influenced by composition. Knowing the composition of milk also helps to assess of adulteration and the quality of the milk for consumers and milk processing industries. The price of milk and consumers interest varies with milk components, whichmay directly affect the farm income. Despite small contribution of camel and goats, almost $97 \%$ of milk is coming from cows. In addition to its nutritional value, it is also a means of generating income (CSA, 2008). In the livestock development policy of the country, to increase the yield, improvement of the genetic potential of the indigenous zebu has been conducted through breeding with high-grade exotics. Hence, it is quite common to see a cross Holstein Friesian cows with better adaptability and yield. Different factors may influence the composition of milk (Lindmark-Mansson et al., 2000). Information about variation of milk composition in relation to parity, lactation stage and pregnancy status in crossbred cattleis scant. The present study was designed to assess theeffect of these factors on yield, major composition and $\mathrm{pH}$ of milk of cross Holstein Friesian cows. The farm was established in May, 2009 with about 70

\section{Materials And Methods}

In the study, a total of 40 cross breed Holstein-Friesian lactating cows SHIATS Allahabad Dairy farm. The cows were provided with the hay in the morning and evening and also allowed for field grazing during the day time. In addition, a by-product of brewery factory was also given every day. All cows were maintained in separate barn under spacious, well constructed house especially at night. They have adlibitum water supply.The study animals were classified according to lactation stage. Those cows between 7 to 105 days of delivery were classified as early, between 106 to 210 days as mid and those in between 211 to 315 days under late stage of lactation (Gizat, A., 2004). Milk sampling was carried out in the morning and the daily milk yield was also recorded. The information about the age and parity of cows were obtained from the records available in the farm. Cows up to four years were classified as young whereas those greater than four years as adult. Pregnancy was confirmed by rectal examination. Milk samples were obtained from individual animals by hand milking. After collection, samples were taken to laboratory ofSundereson School of Animal Husbandary\& Dairying SHIATS Allahabad, for analysis. Analysis was done immediately using Ultramilker UL20A milk analyzer machine and done according to the manufacturer's instructions. The $\mathrm{pH}$ was measured by a digital $\mathrm{pH}$-meter as described (Aggadet al., 2010). The raw data were entered into Microsoft Excel work sheet and descriptive 
statistics were calculated in it. For the variables which require multistage sampling (pregnancy and lactation stage) paired t-test and repeated measure analysis of variance were used. For the variables that didn't require multistage sampling (age and parity) independent t-test was used for comparison. All statistical analyses were done using the SPSS version 17 software package. Probability $(P)$ value less than 0.05 was used to determine the level of significance. mid stage of lactation $(7.17 \mathrm{~L} / \mathrm{d})$ followed by the early

\section{Results And Discussion}

In table-1 the mean milk yield was 6.82 and $6.49 \mathrm{~L} / \mathrm{d}$ in young and adult cows, respectively. However, there was no statistically significant difference between the two age groups. The protein and SNF components of the milk were significantly lower $(\mathrm{P}<0.05)$ in young than adult cows. However, significant difference was not observed in fat, lactose and $\mathrm{pH}$ of the milk between age groups. In table-2the mean milk yields per day in nonpregnant and pregnant cows were 6.69 and 5.52 litres, respectively and the variation was statistically significant $(\mathrm{P}<0.05)$.

Table 1: The mean in milk yield and the major components in young and adult cows

\begin{tabular}{lcc}
\hline & Age & Adult \\
\hline Particulars & Young & $6.29 \pm 2.14$ \\
\hline Milk yield, L/d & $6.72 \pm 1.97$ & $8.77 \pm 0.52$ \\
SNF, \% & $8.62 \pm 0.55$ & $4.16 \pm 1.17$ \\
Fat, \% & $3.91 \pm 1.35$ & $3.37 \pm 0.33$ \\
Total protein, \% & $3.28 \pm 0.22$ & $28.24 \pm 2.57$ \\
Density & $28.59 \pm 2.93$ & $4.97 \pm 0.53$ \\
Lactose $\%$ & $4.76 \pm 0.43$ & $6.63 \pm 0.21$ \\
pH & $6.55 \pm 0.21$ & \\
\hline
\end{tabular}

Mean \pm standard deviation (SD)

Table 2: The mean in milk yield and the major components in non- pregnant and pregnant cows

\begin{tabular}{lcc}
\hline & Pregnancy & \\
\hline Components & Non-pregnant & Pregnant \\
\hline Milk yield, L/d & $6.69 \pm 1.49$ & $5.52 \pm 1.33$ \\
SNF, \% & $8.61 \pm 0.81$ & $8.91 \pm 0.69$ \\
Fat, \% & $3.41 \pm 1.62$ & $3.47 \pm 1.56$ \\
Total protein, \% & $3.34 \pm 0.74$ & $3.50 \pm 0.32$ \\
Density & $27.73 \pm 3.21$ & $28.50 \pm 3.01$ \\
Lactose $\%$ & $4.85 \pm 0.44$ & $5.03 \pm 0.57$ \\
pH & $6.60 \pm 0.21$ & $6.63 \pm 0.16$ \\
\hline
\end{tabular}

Mean \pm standard deviation (SD)

The protein, SNF and lactose components of the milk were significantly lower $(\mathrm{P}<0.05)$ in non-pregnant than pregnant cows. However, significant difference was not observed in fat composition and $\mathrm{pH}$ of the milk. In table-3Lactation stage significantly $(\mathrm{P}<0.05)$ affected the milk yield. The highest yield was recorded in period $(6.81 \mathrm{~L} / \mathrm{d})$ and lastly in late of lactation $(5.48 \mathrm{~L} / \mathrm{d})$. The fat content of the milk was statistically different $(\mathrm{P}<0.05)$ in three stages of lactation. It was higher in early and late stages than mid stage of lactation. But no difference was observed in SNF, protein, lactose and $\mathrm{pH}$ of the milk. In table-4 cows were divided into primiparous and multiparous based on the number of calving, it was found that average milk yield was 6.43 and $5.89 \mathrm{~L} / \mathrm{d}$ in primiparous and multiparous cows, respectively. However, it was not statistically significant. The major components (fat, SNF, protein and lactose) and $\mathrm{pH}$ of the milk were also not differing in primiparous and multiparous cows.

Table 3: Mean milk yield and the major components of milk in early, mid and late lactation stages

\begin{tabular}{lccc}
\hline Components & Early lactation & Mid lactation & Late lactation \\
\hline Milk yield, L/d & $6.81 \pm 1.45$ & $7.17 \pm 0.05 \mathrm{a}$ & $5.48 \pm 0.05$ \\
SNF, \% & $8.77 \pm 1.39$ & $8.43 \pm 0.21$ & $8.12 \pm 1.07$ \\
Fat, \% & $4.46 \pm 1.44$ & $3.70 \pm 0.89$ & $4.46 \pm 1.44$ \\
Total protein, \% & $3.55 \pm 1.43$ & $3.17 \pm 0.15$ & $3.33 \pm 0.16$ \\
\hline
\end{tabular}


Effect of Age, Pregnancy, Lactation Stage, Parity and on Yield and Components of Raw Milk in

\begin{tabular}{llll} 
Density & $27.42 \pm 3.60$ & $26.40 \pm 1.92$ & $26.51 \pm 2.81$ \\
Lactose \% & $4.80 \pm 0.56$ & $4.68 \pm 0.41$ & $4.72 \pm 0.50$ \\
$\mathrm{pH}$ & $6.62 \pm 0.17$ & $6.55 \pm 0.20$ & $6.73 \pm 0.16$ \\
\hline
\end{tabular}

Mean \pm standard deviation (SD)

Table 4: The mean in milk yield and the major components in premiparous and multiparous cross Holstein Friesian cows

\begin{tabular}{lcc}
\hline & Parity & Multiparous \\
\hline Components & Primiparous & $5.89 \pm 2.37$ \\
\hline Milk yield, L/d & $6.43 \pm 1.39$ & $8.54 \pm 0.56$ \\
SNF, \% & $8.38 \pm 0.31$ & $3.30 \pm 1.78$ \\
Fat, \% & $3.61 \pm 0.75$ & $3.30 \pm 0.27$ \\
Total protein, \% & $3.23 \pm 0.14$ & $28.44 \pm 4.03$ \\
Density & $26.90 \pm 1.63$ & $4.86 \pm 0.54$ \\
Lactose $\%$ & $4.71 \pm 0.30$ & $6.65 \pm 0.17$ \\
pH & $6.58 \pm 0.20$ & \\
\hline
\end{tabular}

Mean \pm standard deviation $(\mathrm{SD})$

A study on milk yield and milk composition is of most important to evaluate the milk production ability of milking animals. The present study described the effect of stages of lactation, age parity and pregnancy on milk yield and composition in dairy cows of Gondar University. The mean milk yield (5.48 to $7.17 \mathrm{~L} / \mathrm{d})$ in the farm was found to be much lower than that of pure Holstein Friesian cows (8.8 kg), (Metry et al., 1994). But, it was better than the milk yield of local zebu cows (0.5-2 L/d) Tassew and Seifu, (2009). The occurrence of the peak milkyield at the mid of lactation in this study agrees with thereport of Mechet al. (2008) in buffaloes which stated thatmilk yield increased up to 90 days and remain high for awhile and then declines in late stage of lactation. Milk yield was also affected significantly by pregnancy. Thisresult agrees with the report of Akers (2002) who stated thatpregnancy has a negative effect on milk yield. A declinein milk yield with pregnancy in dairy buffaloes was alsoreported by Khan et al. (2011). This may be due to hormonalchanges, causing regression of the mammary gland and nutrient requirements of the foetus, reducing available nutrients for milk production (Bell et al., 1995). Milk yield did not showsignificant variation in different age and parity groups. This may be due to the fact that the farm is establishedonly two years ago that cows are fairly young and calving was not much. Fat content was lowest in mid lactation and significantly increased in early and late lactation stages. The influence of lactation stage on goat milk fat was also reported by Bhosale et al. (2009). The finding in this study was inline with Stoop et al. (2009). However, the finding disagrees with the report of Bohmanovaet al. (2009) who reported that fat content of the milk was lower especially in late stage of lactation. This may be due to differences in breed and other confounding factors between two studies. Unlike stage of lactation, fat content was not significantly varying between different age, pregnancy and parity groups. The solid not fat (SNF) and protein contents of the milk were significantly different in pregnancy and age. related with the general increments in anabolism of major nutrients. Equivalent to this finding were also observed by Casoliet al. (1989) and Dell'Aquilaet al. () in sheep. However, SNF and protein contents of milk were not significantly affected by stage of lactation and parity. In this study, lactose was not significantly affected throughout the lactation stage. Lactose is the main determinant of milk volume. A close relationship between lactose synthesis and the amount of water drawn into milk makes lactose a stable milk component by Pollott (2004). The lactose content of the milk was affected significantly by pregnancy only; other factors didn't affect its composition in milk. Ash content was found to be the least variable of milk component unlike that reported in Fulani cows, West African Dwarf (WAD) does and WAD ewes in Nigeria (Ahamefule et al., 2003). pH did not vary significantly throughout the lactation period. In general, many factors besides nutrition and management can influence milk yield and composition. This is an important point to remember when evaluating the milk quality and in the improvement of milk yield and composition.

\section{References}

[1]. CSA, 2008. Central Statistics Agency, 2008. Statistical 35(6): 375-380. Abstract, Addis Ababa, Ethiopia.

[2]. Lindmark-Mansson, H., U. Svensson, M. Paulsson, G. Alden, B. Frank and G. Johnsson, 2000.

[3]. Influence of milk components, somatic cells and supplemental zinc on milk processability. International Dairy Journal, $10: 423-433$.

[4]. MOA, 2003. Ministry of Agriculture, Budgeting and planning report, summary for North Gondar zone, 2003, Addis Ababa, Ethiopia.

[5]. Gizat, A., 2004. A cross-sectional study of bovine mastitis in and around Bahirdar and antibiotic resistance patterns of major pathogens. MSc Thesis, Faculty of Veterinary Medicine, Addis Ababa University, Debrezeit, Ethiopia. 
[6]. Aggad, H., M. Bridja, Bouhai, Aek, M. Benaouali and A. Djebli, 2010. Some Quality Aspects of Pasteurized Milk in Algeria. World Journal of Dairy and Food Sciences, 5(1): 21-24.

[7]. Metry, G.H., K.A. Mourad, J.C. Wilk and B.T. McDaniel, 1994. Lactation Curves for first lactation Egyptian Buffalo. Journal Dairy Science, 77: 1306-1314.

[8]. Tassew, A. and E. Seifu, 2009. Smallholder Dairy Production System and Emergence of Dairy Cooperatives in Bahir Dar Zuria and MechaWoredas, Northwestern Ethiopia. World Journal of Dairy and Food Sciences, 4(2): 185-192

[9]. Mech, A., A. Dhali, B. Prakash and C. Rajkhowa, 2008. Variation in milk yield and milk composition during the entire lactation period in Mithun cows (Bosfrontalis). Livestock Research Rural Development, 20(5): 56-67.

[10]. Akers, R.M., 2002. Major advances associated with hormone and growth factor regulation of mammary growth and lactation in dairy cows. Journal of Dairy Science, 89(4): 1222-1234.

[11]. Khan, S., M. Subhan, Qureshi, I. Ahmed and S. Shah, 2011. Milk composition and yield changes with advancing pregnancy in dairy buff aloes (Bubalusbubalis). Journal of Veterinary and Animal Sciences, 35(6): 375-380.

[12]. Bell, A.W., R. Slepetis and R.A. Ehrhardt, 1995.Growth and accretion of energy and protein in the gravid uterus during late pregnancy in Holstein cows. Journal of Dairy Science, 78(9): 1954-1961.

[13]. Bhosale, S.S., P.A. Kahate, K. Kapila, V.M. Thakareand S.G. Gubbawar, 2009. Effect of Lactation on PhysicoChemical Properties of local goat Milk.Veterinary World, 2(1): 17-19.

[14]. Stoop, W.M., H. Bovenhuis, J.M. Heck and J.A. VanArendonk, 2009. Effect of lactation stage and energy status on milk fat composition of Holstein-Friesian cows. Journal of Dairy Science, 92: 1469-1478.

[15]. Bohmanova, J., J.J.Jamrozik and F. Miglior, 2009. Effect of pregnancy on production traits of Canadian Holstein cows. Journal Dairy Science, 92: 2947-2959.

[16]. Casoli, C., E. Duranti, L. Morbidini, F. Panella and V. Vizioli 1989. Quantitative and compositional variations of Massases sheep milk by parity and stage of lactation. Small Ruminant Research, 2: 47-62.

[17]. Dell'Aquila, S., A.M. Pilla, G. Catillo, G. Scardella and L. Taibi, 1993. Milk yield of Comisana, DelleLanghe, Massese, Sarda and crossbred ewes. ZootecnicaNutrizioneAnimale, 14: 95-102.

[18]. Pollott, G.E., 2004. Deconstructing milk yield and composition during lactation using biologically based lactation models. Journal Dairy Science, 87: 2375-2387.

[19]. Ahamefule, F.O., J.A. Ibeawuchi and C.A. Ejiofor,2003. Comparative study of the constituents of cattle, sheep and goat milk in a hot-humid environment.Discovery and Innovation, 15: 64-69. 